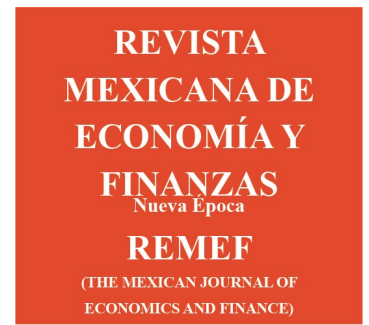
Revista Mexicana de Economía y Finanzas Nueva Época
Volumen 15 Segundo Número Especial Aniversario Agosto $2020 \quad$ pp. $455-472$
DOI: https://doi.org/10.21919/remef .v15i0.541
(Recibido: 12/febrero/2020, aceptado: 9/julio/2020)

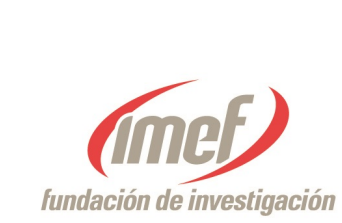

SNEA - Entrepreneurial research in emerging economies: recent advances Editor Invitado: Dr. Samuel Mongrut

\title{
Psychic Distances and the Export Success of Born Globals Firms
}

\author{
Bruce Lezana Zúñiga ${ }^{1}$ \\ Universidad de Chile, Chile \\ Christian Cancino del Castillo ${ }^{2}$ \\ Universidad de Chile, Chile \\ Belén Guede Vicencio ${ }^{3}$ \\ Universidad de Chile, Chile \\ Juan Carlos Salazar-Elena ${ }^{4}$ \\ Universidad Autónoma de Madrid, España
}

\section{Abstract}

This paper investigates how psychic distance from export markets affects internationalization success. Using CORFO (Corporation for the Promotion of Production) data in Chile, two-stage Probit regression models are estimated. The results show that companies that decide to sell at a high psychic distance would have a better chance of success. However, previous experience in ventures would be important when deciding to export over long psychic distances. Thus, policymakers should take those factors into account when making decisions. Some limitations of this study are related to use cross section data, overlooking possible endogeneity problems. Nevertheless, and unlike other previous works, the methodology used tries to correct the inherent selection bias present in the topic investigated. The outcome of this work is important to encourage Chile's born globals firms to focus their operations on the most attractive and distant international markets.

JEL Classification: 01, O2, O3, O4, O5, M2

Keywords: entrepreneurship, psychic distances, born globals, CORFO, Chile

\section{Distancias Psicológicas y el Éxito Exportador de las Born Globals}

\section{Resumen}

Este paper investiga cómo la distancia psicológica con los mercados destinos de las exportaciones afecta el éxito de internacionalización. Utilizando datos de CORFO (Corporación de Fomento a la Producción) en Chile, se estiman modelos de regresión Probit en dos etapas. Por una parte, los resultados muestran que las empresas que deciden vender a una alta distancia psicológica tendrían mayores opciones de éxito. Por otra parte, la experiencia previa en emprendimientos sería importante en la decisión de exportar a altas distancias psicológicas. Así, los responsables de política pública deberían tener en cuenta aquellos factores al momento de tomar decisiones. Algunas limitaciones de este estudio están relacionadas al uso de datos de corte transversal

\footnotetext{
${ }^{1}$ University of Chile, Diagonal Paraguay 257, Santiago, Chile. 8330015, Santiago. blezana@fen.uchile.cl

${ }^{2}$ University of Chile, Diagonal Paraguay 257, Santiago, Chile. 8330015, Santiago. cancino@fen.uchile.cl

${ }^{3}$ University of Chile, Diagonal Paraguay 257, Santiago, Chile. 8330015, Santiago bguede@fen.uchile.cl

${ }^{4}$ Autonomous University of Madrid, Campus de Cantoblanco, 28049 Madrid. juancarlos.salazar@uam.es *Sin fuente de financiamiento para el desarrollo de la investigación
} 


\section{Resumen}

pasando por alto posibles problemas de endogeneidad. Sin embargo, y a diferencia de trabajos previos, la metodología utilizada intenta corregir el inherente sesgo de selección presente en el tópico de investigación. Los resultados de este trabajo son importantes para fomentar en Chile a que sus born globals enfoquen sus operaciones en los más atractivos y lejanos mercados internacionales.

Clasificación JEL: O1, O2, O3, O4, O5, M2

Palabras Clave: emprendimiento, distancias psicológicas, born globals, CORFO, Chile.

\section{Introduction}

Over the years, entrepreneurship has been considered a key element in the development of countries. Classic authors (Schumpeter, 1934; Leibenstein, 1968) through to contemporary authors (Zsuzsanna \& Herman, 2012; Toma, Grigore, \& Marinescu, 2014; Liñán \& Fernandez-Serrano, 2014) have understood the importance of entrepreneurship in well-being through employment creation, income growth and innovation.

A special type of international entrepreneurship is known as born global firms, which are defined as firms that present an accelerated process of internationalization, meaning they initiate their commercial activities immediately in international markets or do so in a period relatively close to their foundation (McDougall, Shane \& Oviatt, 1994; Coviello \& Munro, 1995; Autio, Sapienza \& Almeida, 2000; Knight \& Cavusgil, 2004). These firms present different characteristics to the gradual internationalization model, or Uppsala model, which asserts that firms develop an incremental internationalization process (Johanson \& Vahlne, 1977). Thus, in several academic studies a growth in global born ventures has been indicated, which can be explained by factors linked to more customized products or services, advances in transportation, greater market information, sturdier international networks or even more and greater financing options (Knight \& Cavusgil, 1996; Madsen \& Servais, 1997; Oviatt \& McDougall, 1997; Autio, 2005; Smolarski \& Kut, 2011).

However, not only has the speed of the internationalization of firms been a subject of study for born globals. Choosing the destination economies for exports has also been a subject of scientific interest. Some studies have emphasized the role that geographical and psychic distances can play, particularly in terms of how any cultural differences existing between the country in which a born global firm is founded and the countries in which it decides to export may affect the internationalization process of new firms (Cancino, 2014; Ojala, 2015; Bhowmick, 2018; Magnani, Zucchella \& Floriani, 2018). Nevertheless, the previous research does not show the same results depending on the economy analysed. In the case of emerging countries, some studies show that there are differences in the characteristics and distances of customer countries from born globals firms compared to developed countries (Ciravegna, Lopez \& Kundu, 2014). This suggests that although the phenomenon of born global firms is prevalent throughout the world, it would not be homogeneous among different types of countries and could change according to the economic, social and cultural context (Bruton, Ahlstrom, \& Obloj, 2007). Thus, it is not clear which factors are related to existance and success of this type of entrepreneurships. Consequently, understanding the behaviour of born global firms can be very relevant in terms of public policies, considering the impact they can have on the development potential of countries.

As a result of the significant positive influence that a greater number of born global firms have on an economy, which are not only active internationally, but also generate a series of profit spills in the domestic market (Cancino, 2014), a series of public productive support programs have been developed in each country that seek to strengthen the founding and subsequent development of firms with international activities. The success of these programs and the effect they have on boosting the development of born globals firms is not always evaluated.

This paper aims to evaluate the factors that determine the success of new Chilean firms supported 
by $\mathrm{CORFO}^{5}$ 's productive promotion programs in Chile in their venture into international markets. For this purpose, a Probit regression model was conducted in two stages, which seeks to show the factors and characteristics that impact on the probability of export success of Chilean fims supported by CORFO. Given the fact that, in general, entrepreneurs supported by $\mathrm{CORFO}$ value internationalization as a growth strategy even before being approached by CORFO, the two-stage method used in this work intends to correct the possible self-selection bias existing in the sample (Heckman, 1976).

While there is a wide literature examining the phenomenon of born global firms and the way public programs that support them work, there is less evidence that considers the inherent possible selection bias that exists when generating models that explain the characteristics and factors that determine a firm's internationalization process. This bias would come from the fact that when one tries to measure a born global firm through variables such as the level of international sales or participation in foreign markets, it is not considered that these firms made a decision beforehand, which is to decide to participate in the international market. This previous decision, which is not random, generates a possible self-selection bias in the sample, that is, firms that have already decided to participate internationally. This must be corrected to reach more reliable estimates. The two-stage Probit method that we performed in this study is quite innovative and aims to give value to research.

According to the first Probit regression model results, it is demonstrated that there is indeed a selection bias in the sample. In the case of the sampled firms, all are defined as firms whose international focus is part of the core values. Nevertheless, the distances or differences with their export destination markets is not consistent. The findings suggest that new firms selling over a long psychic distance would be more likely to succeed in international markets than their peers exporting to nearby countries in the region. Choosing Asian, North American, and European markets is critical to growth and export success. In this sense, being global and not regional (not Latin America countries in this case) is essential to achieve export success. Considering the importance of psychic distances in explaining the success of the internationalization of new companies, we also developed a second Probit regression model in two stages, where the factors that influence the probability of deciding whether or not to sell at a high psychic distance are determined. The results of this second model show that, although there does not seem to be a selection bias that could affect the estimates, the fact of having received private capital in the domestic market has a negative impact on the decision to sell long distance, while having more experience in previous ventures has a positive and significant impact on this probability. Namely, raising capital in Chile fosters the growth of commercial activities in the region's nearby markets over markets that are psychically distant. It would appear that the domestic investor prefers higher short term returns, although these may be less than the adventure of marketing products in distant markets, but where the probabilities of risk may be greater. In contrast, the past experience of entrepreneurs positively influences the choice of psychically distant markets, where the experience of creating companies, with successes or failures, is a fundamental resource for the international strategy of the born globals founders.

The findings described could be very important in supporting policy-making in Chile, or in countries of the region with a similar level of development, where the national strategy is oriented towards the large markets of Asia, North America and Europe. It is precisely these economies that require important products from the region, and the participation of new companies is essential.

The work is structured as follows. After this introduction, section two presents the literature review and research hypotheses. Section three presents the research methodology. Section four presents the results. Section five presents the discussions of the study. A final section presents the findings of the study.

\footnotetext{
${ }^{5}$ Chilean Corporation for the Promotion of Production
} 


\section{Literature Review and Hypothesis}

There is ample literature related to born globals companies and the internationalization process that underlies these firms. In this respect, there are studies that have tried to explain the behaviour and determinants that define a born global and differentiate it from a company that performs a gradual internationalization process, both in emerging and developed economies (Sapienza, Autio, George, \& Zahra, 2006; Persinger, Civi \& Vostina, 2007; Cancino, 2014; Cancino \& Coronado, 2014; Cumming, Fischer \& Peridis, 2014). More recent research has emphasized the importance of geographical and psychic distances in choosing the markets to participate in and their impact on the internationalization of SMEs (Håkanson \& Ambos, 2010; Ojala, 2015; Magnani, Zucchella \& Floriani, 2018; Bhowmick, 2019).

Smolarski and Kut (2011) conducted an analysis of small and medium-sized enterprises with fewer than 100 employees. To do so, they considered a sample of 186 Swedish firms that received financing or some form of private capital. According to an Ordered Probit regression model, an attempt was made to explain the firms' performance and internationalization level, using the sales rate and export ratio as proxies, respectively. The findings of this research show that there would be a significant relationship between the type of financing received, which could be incremental, lump sum or syndicated and the performance and level of internationalization of a firm. This relationship would be positive when firms acquire funds incrementally and syndicated on a separate basis and negative when the firm acquires both at the same time.

Meanwhile, Cancino and Coronado (2014) used a logistic regression model on a sample of 115 small and medium Chilean companies that decided to internationalize, in order to explain their behaviour and understand what variables define that these firms can be considered born globals. The findings of this study show, among other things, that networks with international capital and the cultural distance from countries that receive exports have a positive impact on the likelihood a firm could be considered a born global. Along the same lines, Cancino (2014) conducted an analysis of 112 Chilean SMEs with regular exports. The results of this study are similar, finding a positive influence from national and international networks and the psychic distance with respect to the probability of behaving as a born global, and also the absence of companies participating in the high technology sector within these types of companies. The latter is a particular case of international born globals.

In the same context of emerging economies, Dib, da Rocha and da Silva (2010) seek to examine the phenomenon of born globals in Brazil. To do so, they conducted a logistic regression model on a sample of 79 software firms, which were divided between companies with born global characteristics and firms with a gradual process of internationalization. The results found in this study show that some variables such as innovation and customer orientation may have a positive impact on the type of process that the firm undergoes to internationalize. In addition, in a qualitative analysis Persinger, Civi and Vostina (2007) studied the reasons, characteristics and success factors that may be related to born global in emerging economies. These factors may be associated with variables such as the entrepreneurs' personality and previous international experience, risk propensity, among others. With regard to previous experience, studies such as Hollender, Zapkau and Schwens (2017) show consistent results with the above. The authors use a hierarchical linear regression to measure the international performance of firms, finding a positive relationship between previous international experience and the firm's performance abroad. Similarly, Colombo and Grilli (2005) found a positive relatioship between prior entrepreneurial experiences and firm growth for new technology-base firms. The above is consistent with other studies which propose firms managed by prior experienced entrepreneurs would be more probable to persue an early and proactive mode of internationalization (Sapienza, Autio, George, \& Zahra, 2006; Federico, Kantis, Rialp, \& Rialp, 2009).

Other writers, in turn, have presented extensions to the born global phenomenon. One such case is the 
one that literature calls born again global (Bell, McNaughton \& Young, 2001; Bell et al., 2003; Jantune, Nummela, Puumalainen \& Saarenketo, 2008; Schueffel, Baldegger \& Amann, 2014). Bell, McNaughton and Young (2001) define it as firms that are well established and have had a previous focus on their domestic market, but suddenly have a rapid internationalization process. Qualitative studies such as Bell et al. (2003) and Schueffel, Baldegger and Amann (2014) point out that events that provide firms with both financial and human resources could lead to a company becoming a born again global, as well as having a reduced local market and identifying opportunities in other markets. Bell et al. (2003) also indicate that the main competitive advantage of this type of company would be related to a greater knowledge base.

On the other hand, in a quantitative analysis, Jantune et al. (2008) found differences in the factors that would explain the international performance of born globals, born-again globals and traditional companies. The authors use a linear regression model for each of the three groups mentioned above. Their results suggest that the learning orientation would be related to greater performance of born again globals, while there would be a moderate positive relationship between business orientation and the born again globals performance.

Other recent research has analysed the implications of geographical, cultural and psychic distances on the phenomenon of international business. Håkanson and Ambos (2010) conducted a background study on psychic distance. To perform their analysis, the authors used a sample of 1,414 observations from 25 countries, which consider both developed and emerging countries. The results of this study show that most of the variability in the perception of psychic distance would be explained by geographic distance, to the detriment of cultural distance, which does not seem to have a strong relationship. Consequently, the authors recommend giving greater emphasis to greographic distance when attempting to model situations in which psychic distance may play an important role.

Magnani, Zucchella and Floriani (2018) conducted a comparative analysis to complement previous studies related to the internationalisation process of companies. In their research, the authors compared the experience of three Brazilian firms that have internationalized in Italy and three Italian firms that have internationalized in Brazil. Some of their conclusions suggest that a key factor for companies in the decision to access a foreign market would be the firm's specific strategic objectives. To this extent, if the firm considers that entering a particular market is part of a strategic decision, that objective may even counteract the perception of high psychic distance. Additionally, psychic distance should not necessarily be seen as a barrier to international markets, but rather as an appealing factor as it represents an opportunity and fits the firm's strategy, which could potentially play an important role in the internationalization process (Bhowmick, 2019).

\subsection{Research Hypothesis}

All the above could show that the factors determining the existence of born globals are multiple and there may be interactions between different variables, which may have different effects if they are presented together versus those that would be presented in a separate analysis. Such may be the case of psychic distances, which, on the one hand, could represent a barrier to accessing international markets (Upsala model hypothesis), but on the other hand, could also be an opportunity, especially when there is a strategic decision underlying the process of accessing international markets (Magnani, Zucchella \& Floriani, 2018; Bhowmick, 2019), where countries with a high psychic distance may become more appealing as the economy implies growth and profitability (Cancino, 2014). According to the latter, a firm that manages to sell at a high psychic distance would provide a favorable sign that it previously evidenced a suitable opportunity with its strategy, that is, it pursued opportunities in the most demanding international markets, which in the case of Chile, are all psychically distant. This should mean that Chilean companies that manage to sell at a long distance have a better chance of success in international markets. 
$H_{1}$ : Firms that decide to sell at a high psychic distance would have a better chance of success in the international market.

The decision to export over a long psychic distance, in turn, could be influenced by other additional factors besides the strategy, such as the entrepreneur's previous experience or level of risk propensity . In this sense, an individual who has undertaken previous ventures would most likely have a lower risk propensity, greater knowledge of how markets work and more experience (Federico, Kantis, Rialp, \& Rialp, 2009). Some authors have proposed firms managed by prior experience entrepreneurs have higher chances to venture in and early successful internationalization process (Sapienza, Autio, George, \& Zahra, 2006; Persinger, Civi, \& Vostina, 2007). Meanwhile, other empirical studies confirm a possitive relatioship between prior experience and early internationalization success. As such, a firm whose entrepreneur has had previous experience would

be expected to be more likely to venture into international markets, and in turn, into countries with a high psychic distance due to the lower risk propensity and the greater knowledge about markets.

$H_{2}$ : Firms with entrepreneurs who have undertaken previous ventures would be more likely to participate in the international market at a high psychic distance.

\section{Data and Research Methodology}

\subsection{Self-selection Bias Problem}

The series of previous studies that aim to understand the characteristics of born globals business have not addressed the possible selection bias that may be present when working with truncated dependent variable samples. This could affect the true value of the effect of the analyzed variables.

The problem of selection bias can occur when we encounter samples that are not random, because the same individuals in the sample decided to participate, so there is a possibility that they have certain characteristics of a portion of the population, which do not necessarily represent the population as a whole (Heckman, 1979).

In the case of the various born globals studies, there may be an inherent bias when trying to explain the performance of new firms in international markets, especially if they are supported by public programs where one of the filters is international market orientation. This may occur because work is being conducted with samples of firms that have previously decided to participate in foreign markets, that is, we only know the performance of firms which already participate in the international market, but we do not know the performance of firms that have not yet made such a decision. Consequently, the samples may not be random or representative of all the new companies, biasing the estimates, reaching erroneous conclusions.

Several papers have dealt with the problem of self-selection bias, which derive from different areas of study within economics and business (Campa \& Kedia, 2002; Constant \& Massey, 2003; Chaney, Jeter \& Shivakumar, 2004; Kirkeboen, Leuven \& Mogstad, 2016). For example, within the context of behavioural strategies adopted by firms, Campa and Kedia (2002) studied the destruction of value affecting firms that decide to diversify their activities in different industries. The authors question the results documented by previous studies, pointing out that such research does not control the possible selection biases and endogeneity existing in the study variable. As a result, a regression model is proposed, which by means of the Heckman's correction would manage to control the problems previously mentioned. Finally, the authors manage to show that by controlling for these problems, diversification creates value in the firms. In turn Chaney, Jeter and Shivakumar (2004) undertake a similar approach, in which they seek to explain the existence of "big five premium" in the tariffs of auditing companies. The authors show that this premium disappears once the self-selection bias within the estimates is taken into account. 
When analyzing the determining factors of born global companies in Chile, the study of selection bias is fundamental. Hence the value of this research as the first case that analyzes the factors within a group of companies with international focus and manages to explain what export success and the choice of export destination markets are dependent on.

\subsection{Data and Model}

In order to conduct a quantitative analysis, the data provided by CORFO's Entrepreneurship database in Chile was used. The database considers 6001 observations of projects that applied for CORFO entrepreneurship support programs between 2001 and 2018 and resources were allocated in the corresponding years. The advantage of this database is that it provides a follow up of the companies over time, which allows estimates to be made considering a base year and a common time frame.

Due to the fact that this study aims to study companies that could be characterized as born globals, only companies that received financing between 2012 and 2017 were taken into account, which, by definition of the programs considered within the database, fall into the category of small and medium enterprises (SMEs). Consequently, and considering the variables chosen for both models, the database included 563 observations for the first model and 197 observations for the second model.

Thus, the research method considered two different models. The first was a two-stage Probit regression model, also known as Heckprobit, which sought to test the first hypothesis. On the other hand, the second model, which was also carried out in two stages, sought to test the second hypothesis, according to which greater previous experience in ventures would determine a higher probability of venturing into a market of greater psychic distance.

Accordingly, as mentioned in the previous section, the proposed model seeks to correct any self-selection bias. In order to do this, a selection model was defined in the first stage. This model intends to explain the probability of a firm deciding to internationalize, which is a previous decision both to sell at a high psychic distance and to sell in international markets. In this line, it is necessary to find one, or more, variables that are related to the probability of internationalization, but that are not related to the probability of the firm's success or the probability of selling at a high psychic distance. This variable is known as a selection variable. Precisely for this purpose, the variable "Program" was chosen as the selection variable. This variable represents the program from which the firm received support. Although CORFO aims to support enterprises that have a high degree of innovation per se, it is understood that its programs target companies with different approaches and degrees of innovation. The justification of this variable underlies part of the literature, which points out that within the variables that can influence the degree of internationalization, factors associated with business orientation can be found, such as the degree of innovation, proactivity and nature of risk (Covin \& Slevin, 1991; Morris \& Sexton, 1996; Ripollés-Meliá, Menguzzato-Boulard \& Sánchez-Peinado, 2007).

The two statges model that seeks to correct selection bias can be represented as follows it is assumed that there is an underlying relationship between a set of independent variables and a non-observable latent variable linearly related to the variable of interest, which we define as $\mathrm{Y}^{*}$.

$$
Y^{*}=X \beta+\varepsilon
$$

So we observe only a binary result, which can be represented through a Probit model by means of a standard normal distribution.

$$
\hat{P}_{i}=\Phi(X \beta)=\frac{1}{\sqrt{2 \pi}} \int_{-\infty}^{X \beta} e^{\frac{s^{2}}{2}}
$$

Where: $Y=1$ if $Y^{*}=(X \beta+\varepsilon)>0$ 
At the same time, a selection model is defined, which, in this case, seeks to explain the decision to internationalize.

$$
Q^{*}=Z \theta+\mu
$$

Where $\mathrm{Z}$ is the matrix that contains the independent variables of the selection model and $\theta$ is the parameter vector to be estimated that is associated to the model. Similarly, in this case we observe a binary result Q, which might be represented by a probit model as well. It can be noted that, since internationalizing is a previous decision, the dependent variable $\mathrm{Y}$ will be observed only if the following is known

$$
Q=1 \quad \text { if } \quad q^{*}=(Z \theta+\mu)>0
$$

Where

$$
\begin{aligned}
& \varepsilon \sim N(0,1) \\
& \mu \sim N(0,1) \\
& \operatorname{Corr}(\varepsilon, \mu)=\rho
\end{aligned}
$$

Consequently, in so far as $\rho$ (Rho) is different from 0 , then the selection bias would be significant in the estimates when applying a standard Probit estimation method. Additionally, as mentioned, there must be at least one variable that explains the selection variable, but does not explain the variable of interest. The above implies that the set of explanatory variables $\mathrm{X}$ is a subset of $\mathrm{Z}$.

$$
X \subseteq Z=>Z=\left\{X, Z_{i}\right\}
$$

On the other hand, coefficients of the model were estimated using an optimization process. the function to maximize is the tipical log likelihood function of this type of models, which in this case is represented as follows:

$$
\ln (L)=\sum_{i=1 ; y_{i}=1, Q_{i}=1}^{n} \ln \left[\Phi_{2}\left(X_{i} \beta, Z_{i} \theta, \rho\right)\right]+\sum_{i=1 ; y_{i}=0, Q_{i}=0}^{n} \ln \left[\Phi_{2}\left(-X_{i} \beta, Z_{i} \theta,-\rho\right)\right]+\sum_{i=1 ; Q_{i}=0}^{n} \ln \left[1-\Phi_{1}\left(Z_{i} \theta\right)\right]
$$

Where $\Phi_{2}$ is the cumulative bivariate normal distribution function, whereas $\Phi_{1}$ is the standard cumulative normal distribution.

Table 1 and 2 show the descriptive statistics of the variables considered in each of the models, respectively. A summary of the variables considered is presented in Tables 3 and 4.

Table 1. Provides descriptive statistics for the variables selected for the first model

\begin{tabular}{|c|c|c|c|c|c|}
\hline Variables & Obs & Mean & S.D & Min & Max \\
\hline Success & 563 & 0.268 & 0.443 & 0 & 1 \\
\hline Diversity & 563 & 0.369 & 0.483 & 0 & 1 \\
\hline Internationalize & 563 & 0.517 & 0.500 & 0 & 1 \\
\hline National capital & 563 & 0.320 & 0.467 & 0 & 1 \\
\hline Foreign capital & 563 & 0.057 & 0.232 & 0 & 1 \\
\hline distancia & 563 & 0.151 & 0.358 & 0 & 1 \\
\hline N*participants & 563 & 2.947 & 1,183 & 1 & 10 \\
\hline Funding & 563 & 28,925 & 15,953 & 1.964 & 60,000 \\
\hline \multicolumn{7}{|c|}{ Source: Author's own. } \\
\hline
\end{tabular}


Table 2. Provides descriptive statistics for the variables selected for the second model.

\begin{tabular}{|c|c|c|c|c|c|}
\hline Variables & Obs & Mean & S.D & Min & Max \\
\hline Psychic distance & 197 & 0.152 & 0.360 & 0 & 1 \\
\hline Previous entrepren. & 197 & 0.924 & 0.266 & 0 & 1 \\
\hline Mentor & 197 & 0.731 & 0.445 & 0 & 1 \\
\hline Internationalize & 197 & 0.558 & 0.498 & 0 & 1 \\
\hline Private funding raising & 197 & 0.046 & 0.209 & 0 & 1 \\
\hline Funding & 197 & 31,107 & 17,135 & 3,750 & 60,000 \\
\hline
\end{tabular}

Table 3. Key variables for the first model

\begin{tabular}{|c|c|c|}
\hline Variable & Type & Description \\
\hline Success & Dummy variable takes a value of 0 for no and 1 for yes. (dependent variable). & $\begin{array}{l}\text { has the company sold } \\
\text { and survived in } 2017 ?\end{array}$ \\
\hline Funding & Continuous variable ranging from 1,964 to 60 million (in chilean coin). & $\begin{array}{l}\text { Amount of money } \\
\text { received from CORFO }\end{array}$ \\
\hline Nparticipants & Continuous variable ranging from 1 to 10 . & $\begin{array}{l}\text { Number } \\
\text { of participans }\end{array}$ \\
\hline Internationalize & $\begin{array}{l}\text { Dummy variable takes a value of } 0 \text { for no and } 1 \text { for yes. } \\
\text { (dependent variable in selection model). }\end{array}$ & $\begin{array}{l}\text { Has the enterprise } \\
\text { been internationalized? }\end{array}$ \\
\hline Diversity & Dummy variable takes a value of 0 for no and 1 for yes. & $\begin{array}{l}\text { Has the entrepreneur team at least } \\
\text { one person of different gender? }\end{array}$ \\
\hline Domestic fundraising & Dummy variable takes a value of 0 for no and 1 for yes. & $\begin{array}{l}\text { Has the company received } \\
\text { private national funds? }\end{array}$ \\
\hline International fundraising & Dummy variable takes a value of 0 for no and 1 for yes. & $\begin{array}{l}\text { Has the company received } \\
\text { private international funds? }\end{array}$ \\
\hline Workers & $\begin{array}{l}\text { Categorical variable. } \\
1 \text { if you do not have employees; } 2 \text { if you have between } 1 \text { and } 3 \text { employees; } 3 \\
\text { if you have } 4 \text { or more employees. }\end{array}$ & size of the company \\
\hline Accum domestic sales & $\begin{array}{l}\text { Categorical variable. } \\
1 \text { if you do not have sales in } 2017 ; 2 \text { if you have sales between } 1-5.000 .000 \\
\text { CLP; } 3 \text { if you have sales between 5.000.001-20.000.000 CLP; } 4 \text { if you have } \\
\text { sales between } 20.000 .001-50.000 .000 \text { CLP; } 5 \text { if you have sales greater than } \\
50.000 .000 \text { CLP. }\end{array}$ & National sales level \\
\hline Program & $\begin{array}{l}\text { Categorical variable. } \\
1 \text { if you belong to "Others"; } 2 \text { for PRAE; } 3 \text { for SSAF Desarrollo; } \\
4 \text { for SSAF Innovación; } 5 \text { for SSAF Social. }\end{array}$ & $\begin{array}{l}\text { Program that has } \\
\text { received support }\end{array}$ \\
\hline Sector & $\begin{array}{l}\text { Categorical variable. } 1 \text { for Advertising; } 2 \text { for Biomedicine \& biotech; } \\
3 \text { for Commerce; } 4 \text { for Education; } 5 \text { for Financial \& business services; } \\
6 \text { for Fisheries \& aquaculture; } 7 \text { for Food; } 8 \text { for Fruit, wine and hort; } \\
9 \text { for Health \& pharmaceutical; } 10 \text { for Manufacture; } 11 \text { for Mining \& metalworking; } \\
12 \text { for Others; } 13 \text { for Social; } 14 \text { for TCIE; } 15 \text { for TIC. }\end{array}$ & Industrial sector \\
\hline Product type & Categorical variable. 1 for Hardware; 2 for tangible products; 3 for Service; 4 for Software. & Product category \\
\hline Psycological distance & $\begin{array}{l}\text { Dummy variable. takes a value of } 0 \text { for low (latin american countries) and } 1 \text { for high } \\
\text { (Asian, North american and European countries). }\end{array}$ & Level of psychic distance \\
\hline
\end{tabular}

$$
\text { Source: Author's own. }
$$

Table 4. Key variables for the second model

\begin{tabular}{|c|c|c|}
\hline Variable & Type & Description \\
\hline Psycological distance & $\begin{array}{l}\text { Dummy variable. takes a value of } 0 \text { for low (latin american countries) and } 1 \\
\text { for high (Asian, North american and European countries). (Dependent variable). }\end{array}$ & Level of psychic distance \\
\hline Funding & Continuous variable ranging from 3,75 to 60 million (in chilean coin). & Amount of money received from CORFO \\
\hline Previous entrepreurship & Dummy variable takes a value of 0 for no and 1 for yes. & $\begin{array}{l}\text { Has at least one member made a previous } \\
\text { entrepreneurship? }\end{array}$ \\
\hline Mentor & Dummy variable takes a value of 0 for no and 1 for yes. & Has the company had a mentor or advisory? \\
\hline Internationalize & $\begin{array}{l}\text { Dummy variable takes a value of } 0 \text { for no and } 1 \text { for yes. } \\
\text { (dependent variable in selection model). }\end{array}$ & Has the enterprise been internationalized? \\
\hline Private fundraising & Dummy variable takes a value of 0 for no and 1 for yes. & Has the company received private funds? \\
\hline
\end{tabular}




\section{3. $\quad$ First Model}

The first logistic regression model in two stages seeks to explain the success of enterprises benefited by a CORFO program in the international market. The dependent variable "Success" is a binary variable and is measured through the sales level and the company's ability to survive. Therefore, the Success variable takes the value 1 if the venture effectively achieved sales in 2017 in the international market and in turn managed to survive. If any of the two previous conditions (or both) is not met, the variable takes the value 0. A similar approach is taken by Cancino, Núñez and Merigó (2018), where the authors define "Success" as dependent variable, which takes a value 1 if the company has survived and 0 in another case as well as they consider several industrial sectors in their study, finding some success differences between sectors. Meanwhile, the variable Funding is a continuous variable, which represents the amount of money received from CORFO (public funds). According Arping, Lóránth and Morrison (2010), public funds might have an uncertain effect, due to entrepreneurs may be less concerned to manage costs, but at the same time public support may encourage entrepreneurs to be creative. On the other hand, the variable Nparticipants was considered in the model because of entrepreneurial teams might have an important role in determining venture outcomes, as in the team members share perspectives, different approaches problem-solving, make decisions, among other benefits (de Mol, Khapova \& Elfring, 2015). Internationalize is the dependent variable in the first and second selection model which aims to fix the self-selection bias. In addition, variables Domestic fundraising and International fundraising try to capture the existing relationship between private funds and entrepreneurial international success (Smolarski \& Kut, 2011). Moreover, Workers and Accum domestic sales are variables related to company size. Thus, according their results, Ruzzier and Ruzzier (2015) claim internationalized small and medium enterprises are signifi-cantly larger in terms of sales and number of employees than noninternationalized companies. Another variable taken into account is Program, which is the selection variable in the first and second selection model. On the side of diversity variable, Zimmerman and Brouthers (2012) found a negative relationship between heterogeneous teams (diverse team) and international diversification decision, because of the possible conflict to make decisions. Additionally, Product type was considered as control variable as well. A similar control variable was used by Ellis (2011), where the author aimed to explain how the social ties between entrepreneurs might inhibit internationalization process. Finally, Psycological distance, the main interest variable, was considered to prove Hypotheses 1. This Variable has been tested in several academic studies, finding a tight relationship with internationalization process (Håkanson \& Ambos, 2010; Ojala, 2015; Cancino, 2014; Hollender, Zapkau \& Schwens, 2017; Magnani, Zucchella \& Floriani, 2018; Bhowmick, 2019).

\subsection{Second Model}

The second logistic regression model in two stages seeks to explain why enterprises benefited by a CORFO program decided to sell in the international market. The dependent variable "Psycological distance" is a binary variable and represents the probability of selling at a high psychic distance. Therefore, the Psycological distance variable takes the value 1 if the venture has sales to Europe, North America or Asia-Oceania in 2017 and 0 if it does not. This is in line with Håkanson \& Ambos (2010), who recommend assigning greater importance to geographic distance when generating proxis of psychic distance. The new variables considered in this case were Mentor and the interest variable Previous entrepreneurship. On the one hand, according Bonk Sarmento, de Carvalho and da Rocha Dib (2016), entrepreneurships benefited by accelerator programs increased the speed of internationalization by replacing informal social networks with more formal and structured ones, which were given by mentors. On the other hand, Previous entrepreneurship variable is expected to have a positive effect in the probability to sell in a long Psychic distance, consistently with 
Hollender, Zapkau and Schwens (2017) findings.

\section{Results}

In order to understand the variables which could be most important for ventures to succeed in international markets, a two-stage probit regression model was estimated. The results are shown in Table 5 and 6 . In addition, some performance measures of the model can be seen in Appendix A and B.

Table 5. Firts Selection Model

\begin{tabular}{|c|c|c|c|c|}
\hline Selection model & Coeff. Est & $95 \% \mathrm{CI}$ & $\mathbf{Z}$ & P-value \\
\hline \multicolumn{5}{|l|}{ Internationalize } \\
\hline \multicolumn{5}{|c|}{ Program (base $1=$ Others) } \\
\hline$=2, \mathrm{PRAE}$ & $-0.239^{* * *}$ & $(-0.348--0.131)$ & -4.307 & 0.000 \\
\hline$=3$, SSAF Desarrollo & $-0.411^{* * *}$ & $(-0.566--0.256)$ & -5.185 & 0.000 \\
\hline$=4$, SSAF Innovacion & -0.097 & $(-0.218-0.023)$ & -1.587 & 0.113 \\
\hline$=5$, SSAF Social & $-0.386^{* * *}$ & $(-0.667--0.105)$ & -2.693 & 0.007 \\
\hline Rho & $-0.659^{*}$ & $(-0.931-0.087)$ & 3.11 & 0.077 \\
\hline Observations & 563 & & & \\
\hline
\end{tabular}

For Rho is a Chi-Square test.

Source: Author's own.

First of all, from the defined selection model, it can be observed that the coefficient of the Rho parameter was significant. This suggests that there is indeed a selection bias in the sample and that the estimators obtained from the model presented in Table 6 would be more reliable compared to those obtained using a one-stage estimation method. It can also be noted that the selection variable Program was significant for most of the categories. This leads us to understand that there would certainly be important differences in the probability of internationalizing depending on the type of program to which the enterprise belongs. In the case of SSAF Innovacion there would not be a significant difference, probably because the ventures of this program have a high degree of innovation as well as those of the category Others (Seed Capital and StartUp Chile).

Table 6. First Probit Regression Model with Two-Stage Estimation Method

\begin{tabular}{|c|c|c|c|c|}
\hline Model & Coeff. Est & $\mathbf{9 5 \%}$ CI & Z & P-value \\
\hline \multicolumn{5}{|c|}{ Success } \\
\hline \multicolumn{5}{|c|}{ Workers (base $1=0)$} \\
\hline$=2,1$ to 3 & 0.011 & $(-0.101-0.124)$ & 0.198 & 0.843 \\
\hline$=3,4$ to 10 & 0.065 & $(-0.077-0.208)$ & 0.900 & 0.368 \\
\hline$=4,11$ or more & $0.231^{* *}$ & $(0.028-0.434)$ & 2.226 & 0.026 \\
\hline \multicolumn{5}{|c|}{ Sector (base $1=$ Advertising) } \\
\hline$=2$, Biomedicine \& biotech & $-0.338^{* * *}$ & $(-0.586--0.090)$ & -2.669 & 0.008 \\
\hline$=3$, Commerce & -0.147 & $(-0.465-0.172)$ & -0.903 & 0.366 \\
\hline$=4$, Education & -0.031 & $(-0.339-0.276)$ & -0.199 & 0.843 \\
\hline$=6$, Fisheries \& aquaculture & 0.135 & $(-0.408-0.677)$ & 0.487 & 0.626 \\
\hline Financial \& business serv & 0.018 & $(-0.278-0.313)$ & 0.117 & 0.907 \\
\hline$=8$, Food & -0.057 & $(-0.342-0.228)$ & -0.392 & 0.695 \\
\hline$=9$, Health \& pharmaceutical & 0.037 & $(-0.296-0.370)$ & 0.218 & 0.827 \\
\hline$=10$, Manufacture & 0.129 & $(-0.280-0.538)$ & 0.618 & 0.537 \\
\hline
\end{tabular}




\begin{tabular}{|c|c|c|c|c|}
\hline$=11$, Mining \& metalworking & $-0.338^{* * *}$ & $(-0.586--0.090)$ & -2.669 & 0.008 \\
\hline$=12$, Others & 0.006 & $(-0.260-0.273)$ & 0.046 & 0.963 \\
\hline$=13$, Social & -0.176 & $(-0.482-0.130)$ & -1.125 & 0.261 \\
\hline$=14, \mathrm{TCIE}$ & -0.160 & $(-0.434-0.114)$ & -1.147 & 0.252 \\
\hline$=15, \mathrm{TIC}$ & 0.131 & $(-0.150-0.411)$ & 0.914 & 0.361 \\
\hline \multicolumn{5}{|c|}{ Product type (base $2=$ Tangible products) } \\
\hline$=1$, Hardware & 0.063 & $(-0.147-0.274)$ & 0.587 & 0.557 \\
\hline$=3$, Service & -0.043 & $(-0.179-0.093)$ & -0.623 & 0.533 \\
\hline$=4$, Software & -0.095 & $(-0.227-0.036)$ & -1.417 & 0.157 \\
\hline \multicolumn{5}{|c|}{ Accum domestic sales (base $1=0$ CLP) } \\
\hline$=2,1-5.000 .000$ & $0.296^{* * *}$ & $(0.120-0.473)$ & 3.286 & 0.001 \\
\hline$=3,5,000,001-20.000 .000$ & $0.239^{* * *}$ & $(0.099-0.379)$ & 3.347 & 0.001 \\
\hline$=4,20,000,001-50.000 .000$ & $0.209^{* * *}$ & $(0.053-0.365)$ & 2.625 & 0.009 \\
\hline$=5, \$ 50.000 .001$ or more & $0.320 * * *$ & $(0.200-0.439)$ & 5.239 & 0.000 \\
\hline Diversity & -0.057 & $(-0.148-0.034)$ & -1.228 & 0.219 \\
\hline Nparticipants & 0.020 & $(-0.019-0.060)$ & 1.006 & 0.314 \\
\hline Funding & -0.000 & $(-0.003-0.003)$ & -0.005 & 0.996 \\
\hline Psychic distance & $0.446^{* * *}$ & $(0.327-0.564)$ & 7.361 & 0.000 \\
\hline Domestic fundraising & 0.037 & $(-0.059-0.133)$ & 0.759 & 0.448 \\
\hline International fundraising & $0.243^{* * *}$ & $(0.069-0.418)$ & 2.733 & 0.006 \\
\hline Observations & 563 & & & \\
\hline
\end{tabular}

Source: Author's own.

Based on the model presented in Table 6, four variables are statistically significant: Workers, Accum domestic sales, Psycological distance and International fundraising. Therefore, the results suggest that firms with more workers would be more likely to succeed. This occurs once the threshold of ten workers is exceeded. That is to say, larger enterprises would have a better chance of being successful in the international market. On the other hand, ventures that have higher accumulated domestic sales would have a better chance of success. This finding suggests that, in the case of Chilean ventures supported by CORFO, their previous performance in the domestic market would be an important condition in explaining their possible success in venturing internationally. As for psycological distance, the relationship is positive, indicating that firms venturing to export at a high piscological distance would have a greater chance of international success. This result confirms Hypotheses 1, where either because of the appeal of the international market or as result of a strategic decision, entrepreneurships whose sales come at least in a small proportion from psycological distant markets, they have a higher probability of success.

Table 7. Second Probit Regression Model with Two-Stage Estimation Method

\begin{tabular}{|c|c|c|c|c|}
\hline Model & Coeff. Est & $\mathbf{9 5} \%$ CI & $\mathbf{Z}$ & P-value \\
\hline \multicolumn{5}{|c|}{ Psychic distance } \\
\hline \multicolumn{5}{|c|}{ Workers (base $1=0)$} \\
\hline$=2,1$ to 3 & 0.002 & $(-0.063-0.068)$ & 0.066 & 0.947 \\
\hline$=3,4$ or more & 0.064 & $(-0.062-0.190)$ & 0.999 & 0.318 \\
\hline \multicolumn{5}{|c|}{ Product type (base $1=$ Hardware) } \\
\hline$=2$, Physical product & 0.034 & $(-0.186-0.254)$ & 0.301 & 0.763 \\
\hline$=3$, Service & -0.020 & $(-0.210-0.171)$ & -0.200 & 0.841 \\
\hline$=4$, Software & -0.085 & $(-0.260-0.090)$ & -0.956 & 0.339 \\
\hline
\end{tabular}




\begin{tabular}{|c|c|c|c|c|}
\hline Previous entrepreneurship & $0.621^{* * *}$ & $(0.296-0.946)$ & 3.740 & 0.000 \\
\hline Funding & -0.001 & $(-0.003-0.002)$ & -0.573 & 0.567 \\
\hline Mentor & -0.021 & $(-0.105-0.062)$ & -0.496 & 0.620 \\
\hline Private fundraising & $-0.651^{* * *}$ & $(-0.970--0.332)$ & -4.001 & 0.000 \\
\hline \multicolumn{5}{|c|}{ Selection model } \\
\hline \multicolumn{5}{|c|}{ Internationalize } \\
\hline \multicolumn{5}{|c|}{ Program (base $1=$ Others) } \\
\hline$=2, \mathrm{PRAE}$ & $-0.337^{* * *}$ & $(-0.536--0.138)$ & -3.322 & 0.001 \\
\hline$=3$, SSAF Desarrollo & $-0.533^{* * *}$ & $(-0.901--0.166)$ & -2.842 & 0.004 \\
\hline$=4$, SSAF Innovación & $-0.306^{* *}$ & $(-0.551--0.060)$ & -2.440 & 0.015 \\
\hline$=5$, SSAF Social & -0.351 & $(-0.802-0.100)$ & -1.525 & 0.127 \\
\hline Rho & 0.523 & $(-0.861-0.985)$ & 0.370 & 0.544 \\
\hline Observations & 197 & & & \\
\hline
\end{tabular}

As for the second model, in Table 5, concerning the selection model, we can see that there is no selection bias that significantly affects the results of the Probit model. Additionally, two variables were significant in the subsequent estimation: Previous entrepreneurship and Private fundraising. These results suggest that, on the one hand, a variable that could positively explain the decision to sell at a high psychic distance would be previous entrepreneurship, that is, the previous experience that entrepreneurs have in this type of activity would be important when venturing to countries that are psychically distant from Chile. It is consistent with Hypotheses 2, which claims that less risk averse and more experienced entrepreneurs would have a higher probability to participate in high psychically distant markets.

\section{Discussion of the Results}

Quite often entrepreneurial literature talks about different types of ventures. It clasiffies entrepreneurships depending on their features and the proccess they carry out to boost their activities, either in a domestic level or in an international level. In this respect, the last decades evidence has shown a special type of companies, which are characterized by a accelerated internationalization proccess, well-known as born globals. This evidence goes in the oposite direction to the classic internationalization "Uppsala" model.

Despite the fact there are plenty of studies who try to explain the features to define born globals existance, which might be associated with financing received, geografical or psicological distance, previous experience, among other variables, not too many studies have analized what are the determinants of success for these kind of firms. Under the reasonable assumption born globals might behave in a different way than ventures with a slow or more traditional internationalization proccess, it appears not only proper, but also neccesary study those determinants of success to facilitate the best decisions by policymakers. Besides the above, due controls must be taken to prevent possibles estimation biases that may lead to ambiguous results.

Enterprises that venture into selling in markets with a high psychic distance have greater chances of success in the international market. This result confirms hypothesis 1 and may imply that the decision by firms to sell at greater psychic distances would be the result of a strategic decision arising from an identified opportunity in the market, which would be aligned with the competitive advantages of the organization. This could explain the greater probability of success for these firms when they internationalize. 
In the Chilean economy, the markets located close to the domestic market, that is, the Latin American markets, are not only close in terms of the products and services they commercialize, but also in terms of development levels. On the other hand, the attractive markets of the USA, Canada, Asian countries and Europe are all psychically distant, and these markets require Chilean products worldwide, being able to pay more for our products. Hence, exporting to psychically distant countries has greater value for our companies, and allows them to be more successful. Our productive promotion programs should not only promote business internationalization, but also channel efforts so that our entrepreneurs visualize their growth opportunities in the most important international markets, which are all psychically distant (Cancino \& Coronado, 2014; Cancino 2014).

Similarly, previous experience in ventures seems to be a determining factor in deciding to sell at a high psychic distance. This result confirms hypothesis 2 and is consistent with the literature, which indicates that previous experience in the international market and risk propensity would be positively related to the decision to internationalize and access distant markets. Although the variable used does not differentiate between previous national or international experience, it can still be a proxy of both the effect of this variable and the risk propensity.

Thereby, the main results of this research, show that international psicologically long distant markets seem to be more atractive for ventures who are looking for international success. It means entrepreneurships with international presence, should try look for developed markets, where they can find a greater demand. However, entrepreneur features could be crucial into this natural internationalization proccess, where the results suggest more experienced entrepreneur would be more likely to venture into psychically more distant markets. Thus, previous experience or any obervable variable that might explain the entrepreneurial propensity, would be a good sign, not only for the venture itself, but also for who must decide where to place resources to support this type of companies.

In addition, an interesting finding is linked to accumulated domestic sales, which would be strongly related to the probability of success, despite having controlled for firm size. At first glance this result may seem counterintuitive, considering that it contradicts the theory of born globals, according to which born global companies are firms that rapidly move to international markets without the need to have any background in the local market. However, as noted above, some authors have given an extension to the phenomenon of born globals, by referring to companies that while behaving like a born global in the sense of rapid internationalization, have previously had experience in the domestic market, which they have named as born again global (Bell, McNaughton \& Young, 2001; Bell et al., 2003; Jantune, Nummela, Puumalainen \& Saarenketo, 2008; Schueffel, Baldegger \& Amann, 2014). Consequently, it seems that the Chilean firms that have been supported by CORFO present the behaviour of a born again global rather than a born global.

Finally, when studying the performance of firms in the international market, it was confirmed that caution should be exercised with regard to the possible selection bias in the sample that may lead to unreliable results (Campa \& Kedia, 2002; Constant \& Massey, 2003; Chaney, Jeter \& Shivakumar, 2004; Kirkeboen, Leuven \& Mogstad, 2016). The results showed that the effect of selection bias is significant and that results may differ when using a two-stage regression model, which seeks to correct bias, from using a single-stage model.

\section{Conclusion}

This study intends to explain the phenomenon of the born global in the context of Chilean ventures, particularly those ventures that have been supported by CORFO's public programs. The objective was to find factors that could be related to the success of new Chilean companies in the international market, in order to understand the behaviour of these types of companies and how such behaviour may resemble or 
differ from that exposed by literature and international experience.

In order to do this, we tried to consider variables related to the characteristics of the company and variables related to the operating context, as well as possible problems related to the sample and the inherent biases it might have. Consequently, the contribution of this work is twofold: on the one hand, it is methodological, according to which an attempt was made to correct the possible selection bias that exists when working with truncated samples that represent a part of the population. On the other hand, this paper contributes to better understanding the phenomenon of small and medium enterprises internationalization in the context of emerging economies.

From the findings obtained, we also expect to contribute to the extension of the study of born globals in the reality of developing countries. As a result, it can be observed that Chilean companies supported by CORFO would adopt the same behaviour as born again globals, where variables such as previous experience in local markets can be important when defining success in the current internationalization of a business. At the same time, ventures that decide to sell at a high psychic distance, would provide a favorable message that a strategic move would increase the chances of success, especially when choosing the markets of Asia, North America and Europe as the destination of our exports. In this line, such a decision would also be related to the entrepreneur's risk tolerance.

This may be very important both for future public policies when making decisions related to promoting innovation and economic development, as well as for future research, which should take into account potential problems associated with the samples they use when generating models that explain firm performance within a specific context. On the one hand, policymakers or organizations as CORFO might use this results to guide his decision and improve resource allocation when they try to foster international entreprenurships participation. On the other hand, some limitations should be considered when analizing the results. First of all, Psychic Distance variable was created under the assumption every market outside the continent might be considered psychically distant from any chilean venture. Further that, this research consider cross section data, overlooking possible endogeneity between variables as Psychic Distance and Success. Thus, it is unknowing if ventures which export to psychically distant markets are more successful or successful ventures has propensity to participate in psychically distant markets.

This study aims to contribute to international born global literature, the results might be interesting to undertand the chacaracteristics of born global in an emerging economies context. It is proposed for future research to deepen in the secondaries findings of this work, which would suggest born globals in Chile would tend to behave as born again globals and deal with possible endogeneity problems usind panel data.

\section{Referencias}

[1] A. Cancino, C., Nuñez, A., \& M. Merigó, J. (2018). Influence of a seed capital program for supporting high growth firms in Chile. Contaduría y Administración, 64(1), 1-14. doi:10.22201/fca.24488410e.2019.1810

[2] Arping, S., Loranth, G., \& Morrison, A. D. (2010). Public Initiatives to Support Entrepreneurs: Credit Guarantees versus Co-Funding. Journal of Financial Stability, 6(1), 26-35. doi:https://doi.org/10.1016/j.jfs.2009.05.009

[3] Autio, E. (2005). Creative tension: the significance of Ben Oviatt's and Patricia McDougall's article 'toward a theory of international new ventures'. Journal of International Business Studies, 36(1), 9-19. doi:10.1057/palgrave.jibs.8400117

[4] Autio, E., Sapienza, H. J., \& Almeida, J. G. (2000). Effects of Age at Entry, Knowledge Intensity, and Imitability on International Growth. Academy of Management Journal, 43(5), 909-924. doi:10.5465/1556419

[5] Bell, J., McNaughton, R., \& Young, S. (2001). 'Born-again global' firms: An extension to the 'born global' phenomenon. Journal of International Management, 7(3), 173-189. doi:10.1016/S1075-4253(01)00043-6 
[6] Bell, J., McNaughton, R., Young, S., \& Crick, D. (2003). Towards an Integrative Model of Small Firm Internationalisation. Journal of International Entrepreneurship, 1(4), 339-362. doi:10.1023/A:102562942

[7] Bhowmick, S. (2019). How psychic distance and opportunity perceptions affect entrepreneurial firm internationalization. Canadian Journal of Administrative Sciences, 36(1), 97-112. doi:10.1002/cjas.1482

[8] Bruton, G. D., Ahlstrom, D., \& Obloj, K. (2007). Entrepreneurship in Emerging Economies: Where Are We Today and Where Should the Research Go in the Future. Entrepreneurship Theory and Practice, 32(1), 1-14. doi:10.1111/j.1540-6520.2007.00213.x

[9] Campa, J., \& Kedia, S. (2002). Explaining the Diversification Discount. The Journal of Finance, 57(4), 1731-1762. Obtenido de 10.1111/1540-6261.00476

[10] Cancino, C. (2014). Rapid Internationalization of SMEs: Evidence from Born Global Firms in Chile. Innovar, 24(Edición Especial 2014), 141-151. doi:10.15446/innovar.v24n1spe.47614

[11] Cancino, C., \& Coronado, F. (2014). Exploring the determinants of born-global firms in Chile. Academia Revista Latinoamericana de Administración, 27(3), 386-401. doi:10.1108/ARLA-10-2013-0154

[12] Chaney, P. K., Jeter, D. C., \& Shivakumar, L. (2004). Self-Selection of Auditors and Audit Pricing in Private Firms. The Accounting Review, 79(1), 51-72. doi:10.2308/accr.2004.79.1.51

[13] Ciravegna, L., Lopez, L., \& Kundu, S. (2014). Country of origin and network effects on internationalization: A comparative study of SMEs from an emerging and developed economy. Journal of Business Research, 67(5), 916-923. doi:10.1016/j.jbusres.2013.07.011

[14] Colombo, M., \& Grilli, L. (2005). Founders' human capital and the growth of new technology-based firms: A competence-based view. Research Policy, 34(6), 795-816. doi:10.1016/j.respol.2005.03.010

[15] Constant, A., \& Massey, D. S. (2003). Self-selection, earnings, and out-migration: A longitudinal study of immigrants to Germany. Journal of Population Economics, 16(4), 631-653. doi:10.1007/s00148-003-0168-8

[16] Coviello, N. E., \& Munro, H. J. (1995). Growing the entrepreneurial firm: networking for international market development. European Journal of Marketing, 29(7), 49-61. doi:10.1108/03090569510095008

[17] Covin, J. G., \& Slevin, D. P. (1991). A Conceptual Model of Entrepreneurship as Firm Behavior. Entrepreneurship Theory and Practice, 16(1), 7-25. doi:10.1177/104225879101600102

[18] Cumming, D., Fischer, E., \& Peridis, T. (2014). Publicly funded business advisory services and entrepreneurial internationalization. International Small Business Journal, 33(8), 1-16. doi:10.1177/0266242614537849

[19] De Mol, E., Khapova, S. N., \& Elfring, T. (2015). Entrepreneurial Team Cognition: A Review. International Journal of Management Reviews, 17(2), 232-255. doi:10.1111/ijmr.12055

[20] Dib, L. A., da Rocha, A., \& da Silva, J. F. (2010). The internationalization process of Brazilian software firms and the born global phenomenon: Examining firm, network, and entrepreneur variables. Journal of International Entrepreneurship, 8(3), 233-253. doi:10.1007/s10843-010-0044-z

[21] Ellis, P. D. (2011). Social ties and international entrepreneurship: Opportunities and constraints affecting firm internationalization. Journal of International Business Studies, 42(1), 99-127. doi:10.1057/jibs.2010.20

[22] Federico, J. S., Kantis, H. D., Rialp, A., \& Rialp, J. (2009). Does entrepreneurs' human and relational capital affect early internationalisation? A cross-regional comparison. European Journal of International Management, 3(2), 199-215. doi:10.1504/EJIM.2009.024322

[23] Håkanson, L., \& Ambos, B. (2010). The antecedents of psychic distance. Journal of International Management, 16(3), 195-210. doi:10.1016/j.intman.2010.06.001

[24] Heckman, J. J. (1976). The Common Structure of Statistical Models of Truncation, Sample Selection and Limited Dependent Variables and a Simple Estimator for Such Models. Annals of Economic and Social Measurement, 5(4), 475-492. Obtenido de http://www.nber.org/chapters/c10491

[25] Heckman, J. J. (1979). Sample Selection Bias as a Specification Error. Econometrica, 47(1), $153-161$. doi: $10.2307 / 1912352$ 
[26] Hollender, L., Zapkau, F. B., \& Schwens, C. (2017). SME foreign market entry mode choice and foreign venture performance: The moderating effect of international experience and product adaptation. International Business Review, 26(2), 250-263. doi:10.1016/j.ibusrev.2016.07.003

[27] Jantune, A., Nummela, N., Puumalainen, K., \& Saarenketo, S. (2008). Strategic orientations of born globals-Do they really matter? Journal of World Business, 43(2), 158-170. doi:10.1016/j.jwb.2007.11.015

[28] Johanson, J., \& Vahlne, J.-E. (1977). The Internationalization Process of the Firm-A Model of Knowledge Development and Increasing Foreign Market Commitments. Journal of International Business Studies, 8(1), 23-32. doi:10.1057/palgrave.jibs.8490676

[29] Kirkeboen, L. J., Leuven, E., \& Mogstad, M. (2016). Field of Study, Earnings, and Self-Selection. The Quarterly Journal of Economics, 131(3), 1057-1111. doi:10.1093/qje/qjw019

[30] Knight, G. A., \& Cavusgil, S. T. (2004). Innovation, Organizational Capabilities, and the Born-Global Firm. Journal of International Business Studies, 35(2), 124-141. doi:10.1057/palgrave.jibs.8400096

[31] Knight, G., \& Cavusgil, S. T. (1996). The Born Global Firm: A Challenge to Traditional Internationalization Theory. Advances in International Marketing, 8, 11-26.

[32] Leibenstein, H. (1968). Entrepreneurship and Development. The American Economic Review, 58(2), 72-83. Obtenido de https://www.jstor.org/stable/1831799

[33] Liñán, F., \& Fernandez-Serrano, J. (2014). National culture, entrepreneurship and economic development: different patterns across the European Union. Small Business Economics, 42(4), 685-701. doi:10.1007/s11187-013$9520-\mathrm{x}$

[34] Madsen, T. K., \& Servais, P. (1997). The internationalization of born globals: an evolutionary process? International Business Review, 6(6), 561-583. doi:10.1016/S0969-5931(97)00032-2

[35] Magnani, G., Zucchella, A., \& Floriani, D. E. (2018). The logic behind foreign market selection: Objective distance dimensions vs. International Business Review, 27(1), 1-20. doi:10.1016/j.ibusrev.2017.10.009

[36] McDougall, P., Shane, S., \& Oviatt, B. (1994). Explaining the formation of international new ventures: the limits of theories from international business research. journal of Business Venturing, 9(6), 469-487. doi:10.1016/08839026(94)90017-5

[37] Morris, M. H., \& Sexton, D. L. (1996). The concept of entrepreneurial intensity: Implications for company performance. Journal of Business Research, 36(1), 5-13. doi:10.1016/0148-2963(95)00158-1

[38] Ojala, A. (2015). Geographic, cultural, and psychic distance to foreign markets in the context of small and new ventures. International Business Review, 24(5), 825-835. doi:10.1016/j.ibusrev.2015.02.007

[39] Oviatt, B. M., \& McDougall, P. P. (1997). Challenges for Internationalization Process Theory: The Case of International New Ventures. Management International Review, 37, 85-99. Obtenido de http://www.jstor.org/stable/40228434

[40] Persinger, E. S., Civi, E., \& Vostina, S. W. (2007). The Born Global Entrepreneur In Emerging Economies. International Business \& Economics Research Journal, 6(3), 73-82. doi:10.19030/iber.v6i3.3355

[41] Ripollés-Meliá, M., Menguzzato-Boulard, M., \& Sánchez-Peinado, L. (2007). Entrepreneurial orientation and international commitment. Journal of International Entrepreneurship, 5(3-4), 65-83. doi:10.1007/s10843-0070016-0

[42] Ruzzier, M., \& Ruzzier, M. K. (2015). ON THE RELATIONSHIP BETWEEN FIRM SIZE, RESOURCES, AGE AT ENTRY AND INTERNATIONALIZATION: THE CASE OF SLOVENIAN SMES. Journal of Business Economics and Management, 16(1), 52-73. doi:10.3846/16111699.2012.745812

[43] Sapienza, H. J., Autio, E., George, G., \& Zahra, S. A. (2006). A Capabilities Perspective on the Effects of Early Internationalization on Firm Survival and Growth. Academy of Management Review, 31(4), 914-933. doi:10.5465/amr.2006.22527465

[44] Sarmento, C. F., Carvalho, C. A., \& Dib, L. A. (2016). Effectuation and the influence of social networks on the internationalization of accelerated startups. Internext, 11(1), 63-73. doi:10.18568/1980-4865.11163-76 
[45] Schueffel, P., Baldegger, R., \& Amann, W. (2014). Behavioral patterns in born-again global firms Towards a conceptual framework of the internationalization activities of mature SMEs. The Multinational Business Review, 22(4), 418 - 441. doi:10.1108/MBR-06-2014-0029

[46] Schumpeter, J. A. (1934). The theory of economic development. Cambridge: Harvard University Press.

[47] Smolarski, J., \& Kut, C. (2011). The impact of venture capital financing method on SME performance and internationalization. International Entrepreneurship and Management Journal, 7(1), 39-55. doi:10.1007/s11365009-0128-1

[48] Toma, S.-G., Grigore, A.-M., \& Marinescu, P. (2014). Economic Development and Entrepreneurship. Procedia Economics and Finance, 8, 436-443. doi:10.1016/S2212-5671(14)00111-7

[49] Zimmerman, M. A., \& Brouthers. (2012). Gender heterogeneity, entrepreneurial orientation and international diversification. International Journal of Gender and Entrepreneurship, 4(1), 20-43. doi:10.1108/17566261211202963

[50] Zsuzsanna, S. K., \& Herman, E. (2012). Innovative Entrepreneurship for Economic Development in EU. Procedia Economics and Finance, 3, 268-275. doi:10.1016/S2212-5671(12)00151-7

\section{Appendix A}

Model Classification (first model)

\begin{tabular}{|c|c|c|c|}
\hline \multicolumn{4}{|c|}{ True } \\
\hline Prediction (model) & Success & Not Success & Total \\
\hline 1 (Success) & 123 & 138 & 261 \\
\hline 0 (Not Success) & 28 & 274 & 302 \\
\hline Total & 151 & 412 & 563 \\
\hline Sensitivity & \multicolumn{2}{|c|}{$\operatorname{Pr}(1 \mid$ Success $)$} & $81.46 \%$ \\
\hline Specificity & \multicolumn{2}{|c|}{$\operatorname{Pr}(0 \mid$ Not Success $)$} & $66.50 \%$ \\
\hline & \multicolumn{2}{|c|}{ Misclassification } & $29.48 \%$ \\
\hline & \multicolumn{2}{|r|}{ Acurracy } & $70.52 \%$ \\
\hline
\end{tabular}

Cut-off considered in this model was $50 \%$ of probability or more to define the dependent variables as 1. Source: Author's own.

\section{Appendix B}

Model Classification (second model)

\begin{tabular}{|c|c|c|c|}
\hline \multicolumn{4}{|c|}{ True } \\
\hline Prediction (model) & Psychic distance & Not Psychic distance & Total \\
\hline 1 (Psychic distance) & 14 & 19 & 33 \\
\hline 0 (Not Psychic distance) & 37 & 127 & 164 \\
\hline Total & 51 & 146 & \\
\hline Sensitivity & \multicolumn{2}{|c|}{$\operatorname{Pr}(1 \mid$ Psychic distance $)$} & $27.45 \%$ \\
\hline Specificity & \multicolumn{2}{|c|}{$\operatorname{Pr}(0 \mid$ Not Psychic distance $)$} & $86.99 \%$ \\
\hline & & Misclassification & $28.43 \%$ \\
\hline & & Acurracy & $71.57 \%$ \\
\hline
\end{tabular}

Cut-off considered in this model was $50 \%$ of probability or more to define the dependent variables as 1. Source: Author's own. 